\title{
Three Mounds Creek Site, Gregg County, Texas
}

Timothy K. Perttula

Heritage Research Center, Stephen F. Austin State University

Follow this and additional works at: https://scholarworks.sfasu.edu/ita

Part of the American Material Culture Commons, Archaeological Anthropology Commons, Environmental Studies Commons, Other American Studies Commons, Other Arts and Humanities Commons, Other History of Art, Architecture, and Archaeology Commons, and the United States History Commons

Tell us how this article helped you.

This Article is brought to you for free and open access by the Center for Regional Heritage Research at SFA ScholarWorks. It has been accepted for inclusion in Index of Texas Archaeology: Open Access Gray Literature from the Lone Star State by an authorized editor of SFA ScholarWorks. For more information, please contact cdsscholarworks@sfasu.edu. 


\section{Three Mounds Creek Site, Gregg County, Texas \\ Creative Commons License \\ (c) (1) (9)}

This work is licensed under a Creative Commons Attribution-NonCommercial 4.0 International License 


\title{
Three Mounds Creek Site, Gregg County, Texas
}

\author{
Timothy K. Perttula
}

\section{INTRODUCTION}

One of the prehistoric Caddo sites represented in the Buddy Calvin Jones Collections at the Gregg County Historical Museum (GCHM) is the Three Mounds Creck site in Gregg County, in East Texas. The site is GC-68 in the Jones site numbering system (68th site he discovered in Gregg County).

The available information about the site in the GCHM records is sketchy at best. The site had three mounds along Spring (reck, ncar its confluence with the Sabine River, in the Longvicw area. A search of Gregg County 7.5' USGS topographic quadrangles failed to disclose a Spring Creck in the Sabine River basin, so it is likely that the Spring Creek appellation is an informal one used by Jones at the time. Jones' notes also fail to describe the mounds in any fashion, nor their relationship to each other or the landform they were built on, and no map is available that shows the location of the three mounds with respect to wherc he collected artifacts from the site.

\section{RECOVERED ARTIFACTS}

In April 1956. Jones excavated a $9.5 \times 12 \mathrm{ft}$. $(2.9 \times 3.6 \mathrm{~m})$ unit at the site, in an old cotton field. It is unknown if this unit was placed in one of the three mounds, or what the vertical, horizontal, or depositional context of the artifacts from the site in the GCHM collections was. In this work, he recovered 264 artifacts, predominantly ceramic sherds (Table 1), along with a few chipped lithic tools and debris, as well as animal bone and mussel shell fragments. The recovery of these food trash items, and the abundance of ceramic sherds, suggests that Jones' excavation may have been placed in a domestic habitation area at the sitc.

The decorated ceramic sherds from the site include 31 Caddo sherds and one Woodland period rocker stamped sherd. This particular sherd has rows of rocker stamping, but is not large enough to determine if the stamping is zoned by incised lines (cf. varieties of Marksville Stamped, including var. Troyville) or not (cf. Indian Bay Stamped, Tchefuncte Stamped, or Chevalier Stamped) (see Brown 1998:33-34). In any event, the rocker stamped sherd points to a pre-A.D. 850 Woodland period use of the Three Mounds Creek site.

The Caddo sherds from the Three Mounds Creek site are dominated by utility wares, likely cooking and storage jars, decorated with brushed marks on rim and body or incised, punctated, or incisedpunctated vessel sherds (Table 2 ). The relatively high proportion of brushed sherds (58\%) suggests the site was likely to have been occupied sometime after ca. A.D. 1300.

Brushed vessel sherds are a particularly notable feature of Late Caddo ceramic assemblages in the region, but are also a significant part of the ceramic assemblage at Middle Caddo period (ca. A.D. 12001425) mound sites in East Texas such as Washington Square (4INA49, occupied ca. A.D. 1250-1+25) and Oak Hill Village (4IRK214, especially in the Late Village, dating from ca. A.D. 1350-1450). Brushed sherds comprise 55\% of the decorated sherds at Washingtun Square (Perttula 2009:Table 2) and 26.7\% of the decorated sherds in the Late Village at Oak Hill Village (Rogers and Perttula 2004:Table 68). 
34 Journal of Northeast Texas Archaeology 36 (2012)

Table 1. Artifacts recovered from the Three Mounds Creek site (GC-68).

\begin{tabular}{|c|c|c|}
\hline Artifact category & No. & $\%$ \\
\hline \multicolumn{3}{|l|}{ Ceramic Artifacts } \\
\hline Plain rim and body sherds & 210 & 79.6 \\
\hline Decorated body sherds & 32 & 12.1 \\
\hline \multicolumn{3}{|l|}{ Lithic Artifacts } \\
\hline Arrow point preform, quartzitc & 1 & 0.4 \\
\hline Biface fragment & 1 & 0.4 \\
\hline Lithic debris & 14 & 5.3 \\
\hline polishing stone, quartzite & 1 & 0.4 \\
\hline \multicolumn{3}{|l|}{ Eood remains } \\
\hline Animal bones & 2 & 0.8 \\
\hline Mussel shell fragments & 3 & 1.1 \\
\hline Totals & 264 & 100.0 \\
\hline
\end{tabular}

Table 2. Decorated Caddo sherds from the Three Mounds Creek site.

\begin{tabular}{lll}
\hline Decorative Method & No. & $\%$ \\
\hline Utility Wares & 17 & 54.8 \\
Brushed & 1 & 3.2 \\
Brushed-Incised & 6 & 19.4 \\
Incised & 4 & 12.9 \\
Punctated & 2 & 6.4 \\
Incised-Punctated & & 3.2 \\
Fine Wares & 1 & 100.0 \\
Engraved, pendant triangles & 31 & \\
\hline
\end{tabular}


The one fine ware sherd is notable in light of the possibility that the Three Mounds Creek site was occupied beginning in the Middle Caddo period. This is a bottle sherd with at least three horizontal engraved lines on the vessel body, two of which have hatched pendant triangles whose apexes point toward each other. This cngraved decorative element on a bottle is one of the consistently occurring elements in a Middlc Caddo style zone that has been recognized in Caddo communities in the Angelina, Sabine, and Big Cypress stream basins (Hart and Perttula 2010:203-207).

\section{TEMPORAL AND CULTURAL AFFILIATION}

In the absence of radiocarbon dates, or a larger sample of decorated sherds, the teniporal age of the Three Creeks Mound site - or at least the assemblage of Caddo sherds recovered by Buddy Calvin Jones in 1956 - is likely to be from the late 13 th or early 14 th century to the mid-15th century A.D. This is based primarily on the relative proportions of brushed sherds and the one engraved bottle sherd with pendant triangles. Nevertheless, because brushed vessels continued to be made by Caddo groups living in the Sabine River basin into the $17^{\mathrm{h}} \mathrm{h}$ century, it could have been occupied that late. Most likely, but pure speculation, the Three Mounds Creck site may have been occupied at the same time (ca. A.D. 1300 to at least the mid-A.D. 1500s) as the premier Caddo mound center in this part of the Sabine River basin - the Pine Tree Mound site (41HS15, Fields and Gadus 2011; Maki and Fields 2010:293). It may have been a subsidiary mound in a larger political community in this locale.

\section{CONCLUSIONS}

Although the available notes are skimpy, and the information they provide is not particularly substantive, it appears that Buddy Calvin Jones identified and investigated a Caddo mound sitc in Gregg County, Texas, back in 1956. The location of the site-Three Mounds Creek - has not been established on the ground, and the only locational information is that it is situated along a Spring Creek near its confluence with the Sabine River in the Longview, Texas, area. The shape and sizes of the mounds are also unknown.

All that is known at the present time is that Jones excavated a unit $(2.9 \times 3.6 \mathrm{~m}$ in size $)$ on the site and recovered a sinall sample of domestic Caddo artifacts, particularly ceramic sherds. The decorated sherds in the assemblage suggest that the Caddo occupation of the site-and probably the construction of the mounds there-likely took place in the Middle Caddo period (ca. A.D. 1200-1425), but it could have lasted into the 16 th century and beyond, based on the popularity of brushed utility ware vessels in local ceramic assemblages.

\section{ACKNOWLEDGMENTS}

Thanks to Patti Haskins of the Gregg County Historical Museum for making these artifacts from the Three Mounds Creek site available for study. Mark Walters assisted with the analysis effort, which took place on December 17, 2010. 


\section{REFERENCES CITED}

Brown, I. W.

1998 Decorated Pottery of the Lower Mississippi Valley: A Sorting Manual. Mississippi Archaeological Association and Mississippi Department of Archives and History, Jackson.

Fields, R. C. and E. F. Gadus (editors)

2011 Archeology of the Nadaco Caddo: The View from the Pine Tree Mound Site (41HS15), Harrison County, Texas. Prewitt and Associates, Inc., Austin, in press.

Hart, J. P. and T. K. Perttula

2010 The Washington Square Mound Sitc and a Southeastern Ceremonial Complex Style Zone among the Caddo of Northeastern Texas. Midcontinental Journal of Archaeology 35(2):199-228.

Maki, D. and R. C. Fields

2010 Multisensor Geophysical Survey Results from the Pine Tree Mound Site: A Comparison of Gcophysical and Excavation Data. Southeastern Archaeology 29(2):292-309.

Perttula, T. K., with contributions by B. Nelson and M. Walters

2009 Caddo Ceramic and Lithic Artifacts from the Washington Square Mound Site (41 NA49) in Nacogdoches County, Texas: 1985 Texas Archeological Field School Investigations. Bulletin of the Texas Archeological Society 80:145-193.

Rogers, R. and T. K. Perttula

2004 The Oak Hill Village Site (4IRK214), Rusk County, Texas. Document No. 030083. PBS\&J, Austin. 